College of William \& Mary Law School William \& Mary Law School Scholarship Repository

1976

\title{
Nonmilitary Strategies and Competition for Power: The Need for Expanded Regulation of Coercion
}

Walter L. Williams Jr.

\section{Repository Citation}

Williams, Walter L. Jr., "Nonmilitary Strategies and Competition for Power: The Need for Expanded Regulation of Coercion" (1976).

Faculty Publications. 760.

https://scholarship.law.wm.edu/facpubs/760

Copyright c 1976 by the authors. This article is brought to you by the William \& Mary Law School Scholarship Repository. https://scholarship.law.wm.edu/facpubs 


\section{NONMILITARY Strategies AND COMPETITION FOR POWER: THE NEED FOR EXPANDED REgULATION OF COERCION}

\section{By Walter L. Williams, Jr.*}

The general focus of this brief paper is on the use of coercive strategies in the global power process in which states as the principal participants (but also, other groups) strive to maximize power positions-the control over persons, territory, resources, and institutions (political, economic, etc.). Interaction in the use of coercive strategies is in turn a processthe coercion process, in which participants for varying objectives use diplomatic, ideological, economic, and military strategies coercively with deprivational impact ranging from quite low levels (e.g., a mild diplomatic reproach) to extremely high levels (e.g., major destruction of life and property in full scale armed combat). ${ }^{1}$

The more specific focus here is on the use of nonmilitary strategies in this competition for power. As our world community becomes ever more interdependent as to all values, nonmilitary strategies, which may be referred to generally as diplomatic (communications to government officials), ideological (communications addressed to the mass audience comprising the populace of the target state(s)), and economic (restrictions on access to raw materials, goods, services, markets, finances, etc.), can have increasingly coercive impact. Diplomatic communications convey-

* Associate Professor of Law, Marshall-Wythe School of Law, College of William \& Mary.

' This process of coercion is described in detail in M. S. MCDougal \& F. FELICIANo, LAW AND MINIMUM WORLd PUBlic ORder, Ch. 1 (1961). 
ing threats of imminent and substantial military or economic coercion, or propaganda attacks designed to erode popular support of specific governmental policy or to incite revolt, obviously may have major impact upon the target state and achieve the power objectives of the initiator of the coercion more promptly and at far less cost than application of armed force. Global telecommunications technology dramatically increases the ability to bring these strategies to bear. However, the susceptibility today of many states to economic coercion perhaps deserves principal attention. The Arab oil embargo after the Arab-Israeli conflict of October 1973, dramatized the ability of a state, or a group in combination, controlling the major portion of a crucial natural resource to cause substantial damage to national economies. Similarly, one or more states may refuse access to much needed financial institutions, to scientific or technical knowledge, etc., all with quite coercive effects, or they may boycott supplier states, i.e., close access to principal markets for sale of raw materials or finished products. Other effects could be substantial damage to well-being (lower standard of living, hunger, even famine), to the basic power positions of target states, and to other values. Paust and Blaustein, in their article, "The Arab Oil Weapon-A Threat to International Peace,"2 dramatically describe possible immediate outcomes and longer-range effects of such coercion. In short, today, economic strategies could have adverse consequences far more extensive than the bombing of a city or other military actions that would call into play international decisionmaking processes and prescriptions designed to regulate and limit such armed coercion.

Perhaps, the crucial issue for this seminar is the question: Does international law regulate at all the use of economic strategies, and other nonmilitary strategies, having substantial coercive impact? Until this century, states used all strategies, military and otherwise, to whatever levels of coercion desired, without regard to whether they were authorized by law. The long, arduous process of development of community policy seeking maximum emphasis on use of persuasive rather than coercive strategies, and particularly to render significant use of armed force impermissible except for community approved objectives, finally culminated-only in the lifetime of many living today-in the first crude prescriptions of law regulating the use of armed force and the establishment of still highly imperfect community processes of decision to pass on the permissibility of particular applications of armed force. That principal attention has been focused on the application of armed force probably has been, and still is, warranted. Surely, the most crucial need for any community is to establish and maintain legal regulation of armed force. Further, until recent times, the relatively uncomplex economic structures of states, and their lesser degree of interdependence, rendered states less susceptible to prompt and intense coercion from economic strategies, or other strategies. For example, modern means of mass communication have become available just at the time that so many national societies have become especially susceptible to ideological coercion due to hostile per-

${ }^{2} 68$ AJIL 410 (1974). 
spectives based on race, religion, culture, political and economic beliefs, disparity in economic development, etc.

As to the question whether the trend of legal decision has kept pace with economic coercion, I am dubious. One can find a plenitude of formally announced community policy that decisionmakers could apply to determine the permissibility of particular acts of economic coercion. There is the general policy of maintaining minimum world public order, of limiting to the fullest extent possible the substantial deprivation of values and regulating coercion to serve only community approved objectives. One could apply various policy provisions in the UN Charter (the Preamble, Arts. 1 and 2, etc.) and related documents, and regional accords (e.g., Art. 19 of the OAS Charter). In recent years, a series of UN resolutions have condemned economic coercion. A few examples: the 1965 General Assembly's Declaration on Non-Intervention, providing that no state "may use or encourage the use of economic, political or any other type of measures to coerce another State in order to obtain from it the subordination of the exercise of its sovereign rights or to secure from it advantages of any kind."; the General Assembly's 1970 Declaration on Friendly Relations, which repeats this statement; and the Charter of Economic Rights and Duties of States, adopted by General Assembly Resolution 3281 in 1974. These and many other resolutions are cited and discussed at length in Paust and Blaustein.

That these manifold expressions of community policy provide an adequate base to authorize regulation of economic coercion is indisputable (Parenthetically, many of these provisions likewise could be applied to coercive use of diplomatic and ideological strategies.) Some writers find that international law does indeed presently regulate economic coercion. ${ }^{3}$ Others are either strongly suggestive or quite positive that present international law does not regulate economic coercion. ${ }^{*}$ I suggest, reluctantly, that the latter view appears more accurately to gauge the past trend of decision. (I am not referring to the case whether economic coercion in general or in particular detail is regulated by specific agreement between certain states.) I suggest that although community policy favoring regulation of economic coercion exists, the will of decisionmakers to apply that policy and to commit resources to insure adherence to that policy does not, to date. I suggest that we are observing a process of policy development, not application. For prescribed standards of conduct to be law, they must be both authoritative and controlling. I do not see control applied; I do not see in the past conduct of states adherence to prescriptions regulating economic coercion; I do not see governmental expectations that other governments will limit economic coercion to instances authorized by community policy, or else, be effectively

${ }^{3}$ See Paust \& Blaustein, supra note 2.

4 See I. Shihata. Destination Embargo of Arab Oil: Its Legality under International Law, 68 AJIL 591 (1974); J Boorman, Economic Coercion in International Law: The Arab Oil Weapon and the Ensuing Juridical Issues, 9 J. INT'L L. \& ECON. 205 (1974); J. Muir, The Boycott in International Law, id. 187. 
sanctioned for departure from prescription. I note that Messrs. Paust and Blaustein in discussing expressions of community policy cite little if any evidence of past general adherence to that policy, or even of governmental claim of violation of international law by acts of economic coercion, in settings of specific disputes. Even in the case of the Arab oil embargo, with its substantial adverse impact on many states, I have found no governmental claims that such conduct was impermissible under international law. The United States was a principal target of the embargo. Yet, in November 1973, and January 1974, Secretary Kissinger expressed "full understanding" for the Arab action and could "understand reasons" for the embargo. Even as late as March 1974, with the embargo continuing after all the U.S. peace efforts, he resorted only to tougher diplomatic language, without reference to legal claim, that the embargo "could affect the attitude with which we will have to pursue our diplomacy." I know of no governmental communications at that time; no governmental actions initiated in any informal or formal arena that claimed, much less resulted in a decision, that economic coercion in general, or the Arab oil embargo in particular, was subject to regulation under international law. Where is meaningful state conduct? Writers such as Muir, Boorman, and Shihata, ${ }^{5}$ describe a multitude of instances of past resort to substantial economic coercion by states without regard to the question of community authorization. In other sessions at this Annual Meeting, we have heard various lawyers in our government speak of the extensive use of economic coercion by or against the United States, without even raising the question of permissibility of such coercion under international law. There is indeed a "loud silence" on this issue. I submit that in the face of contrary formal expressions of community policy, state conduct implicitly, but overwhelmingly, demonstrates that the past trend of decision has been that states may engage in economic (and other nonmilitary) coercion and counter-coercion without regulation under general international law.

Whether a trend is presently developing toward legal regulation is also uncertain. Policy cries out for it as our economic interdependence rapidly increases and the world community has been sensitized to the problem by the Arab oil embargo. However, we are in what seems to be a retrograde period as concerns commitment to common interests. Substantial additional damage may have to occur from such unregulated coercion before we have policy effectively applied as controlling prescription.

Finally, what might we do to promote accelerated achievement of community policies seeking legal regulation of coercive nonmilitary strategies? Fundamental to this problem is the continuing lack of favorable perspectives of governmental officials. We could work to alter these perspectives by educating officials as to: (a) the increasing global interdependence in all values and the risks thereto entailed in using such strategies; (b) the questionable efficacy in achieving desired objectives through using such strategies, while resulting perhaps in much more

${ }^{5}$ Supra note 4. 
damage than anticipated to all participants through escalating coercion and counter-coercion; and (c) the positive outcomes anticipated from subjecting coercive nonmilitary strategies to regulation under international law. Concurrently, we could also be working on recommendations of more specific prescriptions of policy concerning the use of coercive nonmilitary strategies and of guidelines for decisionmakers in the process of applying those prescriptions in specific cases. As to the criteria to apply, we might study the utility of using much the same criteria as are used in assessing the permissibility of military strategies (e.g., first initiator of coercion, objectives of the coercion, intensity and proportionality of deprivational impact, opportunity for use of persuasive strategies of dispute settlement, opportunity for prior resort to community agencies competent to pass on permissibility of the exercise of the coercion, etc.). ${ }^{6}$ I have disagreed with the above-cited article by Paust and Blaustein to the extent that those writers appear, in this case, too ready to presume general adherence to policy merely because formal expressions of policy exist. Nevertheless, their comprehensive, contextual, policy-oriented approach illustrates how we might seek to accomplish the tasks I have outlined here.

- See McDougal \& FELiciano, supra note 1, especially Ch. 3, for suggestive discussion. 